\title{
EFFECTS OF BEE POLLEN AND PROPOLIS ON PERFORMANCE, MORTALITY, AND SOME HAEMATOLOGICAL BLOOD PARAMETERS IN BROILER CHICKENS
}

\author{
Ivana Klarić 1 , Matija Domaćinović ${ }^{1}$, Vatroslav Šerić ${ }^{2}$ Ivan Miškulin²*, Mirela Pavićc ${ }^{3}$, Ksenija Paradinović ${ }^{2}$ \\ ${ }^{1}$ Faculty of Agriculture, Josip Juraj Strossmayer University of Osijek, Vladimira Preloga 1, ${ }^{2}$ Faculty of Medicine, Josip Juraj Strossmayer \\ University of Osijek, Cara Hadrijana 10E, 31000 Osijek, ${ }^{3}$ Faculty of Veterinary Medicine, University of Zagreb, Heinzelova 55, 10000 Zagreb, \\ Croatia \\ ${ }^{*}$ Corresponding author: E-mail: ivan.miskulin@mefos.hr
}

\begin{abstract}
This experimental study aimed to determine how propolis and bee pollen (each supplement separately or in combination in a certain proportion), as additives to broiler feed, affect performance, mortality and the values of the selected haematological blood parameters in chickens. This experimental study was conducted on 200 Ross 308 chickens of equally distributed sex, which were randomly divided into five groups. Throughout the whole study, the control group of chickens was fed ordinary feed mixture, while the feed mixture that was fed to the experimental groups of chickens contained propolis and/or bee pollen. The average values of body weight of chickens were significantly higher on the $1^{\text {st }}(P=0.001), 2^{\text {nd }}-5^{\text {th }}(P<0.001)$ and $6^{\text {th }}(P=0.002)$ weeks of fattening in the experimental groups of chickens in comparison to the control group; the average values of weight gain of chickens were significantly higher on the $1^{\text {st }}(P<0.001), 2^{\text {nd }}(P=0.002), 3^{\text {rd }}(P<0.001), 4^{\text {th }}(P=0.029)$ and $5^{\text {th }}(P=0.009)$ weeks. Lowermortality was recorded in all the experimental groups in comparison to the control group of chickens $(P=0.031)$. Highervalues of $\mathrm{MCV}(P=0.009)$ and haematocrit $(P=0.015)$ and lowervalues of the leukocyte count $(P=0.029)$ and of the relative ratio of $\mathrm{Mo}(P<0.001)$ were recorded in the experimental groups of chickens in comparison to the control group on the $21^{\text {st }}$ day of fattening. Higher values of the relative ratio of heterophils $(P<0.001)$ and lower values of the relative ratios of lymphocytes $(P<0.001)$ and monocytes $(P=0.027)$ were recorded in the experimental groups of chickens in comparison to the control group on the $42^{\text {nd }}$ day of fattening. The results of this study showed that supplementation with propolis and/or bee pollen improved the general health condition of the chickens and positively affected the performance and the values of the selected haematological blood parameters in the chickens.
\end{abstract}

Key words: natural feeding additives; chickens; health; blood; chicken feeding

\section{Introduction}

Sub-therapeutic doses of antibiotics were often used in livestock breeding to improve production indicators and animal health, but also to control pathogens effectively. However, due to the negative effects of antibiotics, such as antibiotic resistance and the presence of antibiotic residues in the final product, the European Commission banned the use of antibiotics as growth agents in $2006(1,2)$. This

Received:22March 2017

Accepted for publication: 22 January 2018 concern has led many researchers to investigate and look for alternatives to promote growth, including the use of natural supplements as feed additives, which would have positive effects both on the growth of chickens and feed utilization. The latter is also important to please consumers' increased demands for the usage of natural products as alternative additives in foods (3). In this context, research has been done on the use of probiotics, prebiotics, antioxidants, acidifiers, enzymes and various plant products as additives in broiler feeding. Recently, propolis and bee pollen have also been considered as potential new additives $(1,2,4)$. 
Propolis is a natural resinous bee product (5). It is composed of more than $50 \%$ lipophilic substances of leaves, plant resins and balsams, plant latex and vegetable glue. It is approximately $30 \%$ waxes, $10 \%$ essential and aromatic oils, 5\% pollen, and the remaining $5 \%$ is a mixture of different substances such as polyphenolic substances, e.g. flavonoids, organic phenols, ketones and terpenes, as well as organic debris, i.e. wood fragments (6). Moreover, propolis contains minerals, such as $\mathrm{Mg}, \mathrm{Ca}, \mathrm{K}, \mathrm{Na}$, $\mathrm{Cu}, \mathrm{Zn}, \mathrm{Mn}$ and $\mathrm{Fe}$, vitamins $\mathrm{B}_{1}, \mathrm{~B}_{2}, \mathrm{~B}_{6}, \mathrm{C}$ and $\mathrm{E}$, as well as fatty acids and some enzymes (7). Its biological activity depends on the active substances of a polyphenolic fraction, flavonoids for the most part, but also on aromatic acids, esters of phenolic acids, triterpenes, lignans and the like (8). These bioactive components of propolis are responsible for antibacterial, antiviral, antifungal, antiprotozoal, antimicrobial, analgesic, anti-inflammatory, antioxidant, locally anaesthetic, cytostatic, i.e. anticancer, as well as the immunostimulating and immunomodulatory effects of propolis both in humans and animals $(9,10)$.

Bee pollen consists of the male gametophytes of seed plants $(11,12)$. To date, about 250 various chemical compounds have been detected in it, including carbohydrates, fats, proteins, vitamins, macro- and microelements, antibiotics (inhibins), hormones, enzymes, organic acids, essential oils, rutin, and others (11). Bees collect pollen from flowers and mix it with their own digestive enzymes (13). Bee pollen is rich in proteins $(25 \%)$ and essential amino acids. Moreover, it contains $6 \%$ of oils, $51 \%$ of which are polyunsaturated fatty acids; $39 \%$ of polyunsaturated fatty acids are linolenic acid, 20\% palmitic and 13\% linoleic acid. Bee pollen contains more than 12 vitamins (B-complex vitamins, vitamins $\mathrm{A}, \mathrm{C}, \mathrm{D}, \mathrm{E}$ and $\mathrm{K}_{3}$ ), 28 minerals, 11 enzymes or coenzymes and 11 different carbohydrates, which comprise $35-61 \%$ of pollen. Carbohydrates are mainly glucose and fructose. As previously mentioned, bee pollen also contains phytochemicals; flavonoids, carotenoids, terpenes, phytosterols, and polyphenols are the most important among them $(13,14)$. The bioactive compounds of bee pollen include flavonoids, phenolic acids and their derivatives that are responsible for the bactericidal, antiviral, antifungal, analgesic, antiinflammatory, antioxidant, immunostimulating and immunomodulatory effects of these substances in humans and animals $(11,15)$.
This study aims to determine how propolis and bee pollen affect performance, mortality and the values of the selected haematological blood parameters in broiler chickens.

\section{Materials and methods}

\section{Animals and diets}

The study included a total of 200 day-old chickens of the Ross 308 provenance (16). The fattening trial of the chickens was carried out on a family farm in eastern Croatia under the supervision of the Department of Nutrition, Anatomy and Physiology of Domestic Animals, Faculty of Agriculture, University of Osijek. The study was approved by the Ethics Committee of the Faculty of Agriculture in Osijek, Josip Juraj Strossmayer University of Osijek. The total of 200 chickens of the Ross 308 provenance, evenly distributed sexes, were randomly divided into 5 groups (40 chickens in each group), one of which was the control group $(\mathrm{K})$ and the other four experimental groups (P1, P2, P3, P4). For the purpose of more effective monitoring of all the investigated indicators, on the seventh day of the trial, all the chickens were marked with leg rings.

During the study, all the groups of chickens were fattened under the same conditions. Temperature, humidity and lighting in the facility were maintained within optimum limits according to the manufacturer's recommendations for the Ross 308 hybrid. Fattening was conducted on wooden sawdust and lasted for 6 weeks (42 days). During the study, feed and water were given to chickens' ad libitum.

From days 1-21 of the study, chickens were fed a mixture of starter; from days 22-42 of the study, chickens were fed a mixture of finisher. The composition and calculated analysis of feed mixtures used in the chickens fattening are shown in Table 1. Throughout the study the control group (K) of chickens was fed a standard feed mixture without additives, while the experimental groups of chickens (P1, P2, P3, P4) were fed feed mixtures that contained additives - propolis and/ or bee pollen as follows: P1 group: feed mixture + $0.25 \mathrm{~g}$ of propolis $/ \mathrm{kg}$ of feed mixture $+20 \mathrm{~g}$ of bee pollen/kg of feed mixture; P2 group: feed mixture $+0.5 \mathrm{~g}$ of propolis $/ \mathrm{kg}$ of feed mixture; P3 group: feed mixture $+1.0 \mathrm{~g}$ of propolis $/ \mathrm{kg}$ of feed mixture; 
Table 1: The composition and calculated analysis of feed mixtures used in the chicken fattening

\begin{tabular}{|c|c|c|}
\hline \multirow{2}{*}{ Fodders, \% } & Starter & Finisher \\
\hline & day $1-21$ & day $22-42$ \\
\hline Corn grain & 45.00 & 46.10 \\
\hline Flour middling & 2.80 & 3.00 \\
\hline Dehydrated alfalfa & 2.80 & 4.00 \\
\hline Soybean meal & 20.20 & 10.00 \\
\hline Sunflower meal & 4.00 & 4.00 \\
\hline Yeast & 4.00 & 3.00 \\
\hline Full fat soybean & 12.40 & 20.00 \\
\hline Vegetable oil & 3.70 & 5.00 \\
\hline Monocalcium phosphate & 1.20 & 1.20 \\
\hline Limestone & 1.60 & 1.40 \\
\hline Salt & 0.30 & 0.30 \\
\hline Premix* & 1.00 & 1.00 \\
\hline Pigozen 801 & 1.00 & 1.00 \\
\hline Total & 100.00 & 100.00 \\
\hline \multicolumn{3}{|c|}{ Calculated analysis } \\
\hline Crude protein, $\%$ & 21.02 & 19.15 \\
\hline Crude fat, \% & 8.36 & 10.96 \\
\hline Crude fibre, \% & 4.96 & 5.05 \\
\hline Lysine, \% & 1.11 & 0.96 \\
\hline Methionine, \% & 0.66 & 0.61 \\
\hline Tryptophan, \% & 0.26 & 0.23 \\
\hline Calcium, \% & 1.04 & 0.98 \\
\hline Phosphorous, \% & 0.70 & 0.67 \\
\hline $\mathrm{ME}, \mathrm{MJ} / \mathrm{kg}$ & 12.30 & 13.10 \\
\hline
\end{tabular}

*Each $1 \mathrm{~kg}$ of premix contained: Vitamin A 1200000 IU; Vitamin D3 200000 IU; Vitamin E 3000 mg; Vitamin K3 250 mg; Vitamin B1 150 mg; Vitamin B2 600 mg; Vitamin B6 200 mg; Vitamin B12 1 mg; Folic acid 50 mg; Niacin 4400 mg; Ca Panthothenate 1500 mg; Biotin 10mg; Choline chloride 50000 mg; Iron 5000 mg; Copper 700 mg; Manganese 8000 mg; Zinc 5000 mg; Iodine 75 mg; Cobalt 20 mg; Magnesium 750 mg; Selenium 15 mg; Antioxidant BHT 10000 mg; Methionine 100000 mg; Herbal carrier 1000 g.

P4 group: feed mixture +20 g of bee pollen $/ \mathrm{kg}$ of feed mixture. Blending of propolis and bee pollen into the feed mixture was performed in a vertical mixer, and administration of propolis and bee pollen started from the first day of the trial.

\section{Performance}

Individual body weight (BW) of each chicken was measured on the $1^{\text {st }}, 7^{\text {th }}, 14^{\text {th }}, 21^{\text {st }}, 28^{\text {th }}, 35^{\text {th }}$, and $42^{\text {nd }}$ days of fattening period using an Avery Berkel FX 220 electronic scale. Based on the measured values, the average value of the body weight of chickens from all the groups has been calculated, while the difference between body weights served for the calculation of weight gains (WG). During the fattening period, feed consumption (FC) was recorded at weekly intervals for each group of chickens. Based on the total amount of consumed feed and overall weight gain, a feed conversion ratio (FCR) was calculated for the periods between weeks 1-3, 3-6, and for the overall experiment (weeks 1-6). 


\section{Blood sample collection and analysis}

For the entire duration of the study, the mortality of chickens was monitored and recorded on a weekly basis. Blood sampling was performed twice during the study period (on days 21 and 42 of the study), on randomly selected chickens (10 birds from each group). Chickens that were selected for blood sampling on day 21 were used as experimental animals for the monitoring of all the investigated parameters until the end of the study. Blood sampling was performed by the puncture of the wing vein (lat. $v$. cutanea ulnaris) with direct needle injection coupled with a test tube under vacuum. The collected blood samples were analysed for the following haematological parameters (red blood cells (RBC) or erythrocyte count, haemoglobin, haematocrit, mean corpuscular volume (MCV), mean corpuscular haemoglobin $(\mathrm{MCH})$, mean corpuscular haemoglobin concentration (MCHC), white blood cells (WBC) or leukocyte count, differential blood count). Total number of erythrocytes $\left(10^{12} / 1\right)$, as well as the values of haemoglobin $(\mathrm{g} / 1)$, haematocrit (L/1), MCV (fL; $\left.1 \mathrm{fL}=10^{-15} \mathrm{~L}\right), \mathrm{MCH}(\mathrm{pg}$; $1 \mathrm{pg}=10^{-12} \mathrm{~g}$ ) and $\mathrm{MCHC}(\mathrm{g} / \mathrm{L})$ were determined using CELL-DYN 1700 automatic analyser (Abbott Diagnostics, USA). A haemocytometer was used to count the total number of leukocytes $\left(10^{9} / 1\right)$ in the whole blood. The amounts of specific leukocyte types (heterophils-He, lymphocytes-Ly, eosinophils-Eo, monocytes-Mo and basophils$\mathrm{Ba}$ ) were counted in blood smear using MayGrünwald and Giemsa staining by means of an Olympus $\mathrm{CH} 2 \mathrm{O}$ microscope. Laboratory analysis of all the abovementioned blood parameters of broilers was performed at the Department of Clinical Laboratory Diagnostics, Clinical Hospital Centre Osijek. The Wakenell reference values (17) were used to interpret the obtained results of the analysis of the haematological blood parameters of broilers.

\section{Statistical analysis}

Upon confirming normality of data distribution with a Shapiro-Wilkinson test, all data were processed by the methods of descriptive statistics. The numerical variables were described as the mean and standard deviations. The ANOVA and Kruskal-Wallis test were used for the comparison of numerical variables among the groups. The categorical variables were described in absolute and relative frequencies. Fisher's exact test was used for the comparison of categorical variables between the groups. The level of statistical significance was set at $P<0.05$. Statistical analysis was done using the Statistica for Windows 2010 statistical package (version 10.0, StatSoft Inc., Tulsa, OK). Different lowercase letters at the level of statistical significance of $P<0.05$ assigned to the individual values in the tables indicate a statistically significant difference, while the same lowercase letters assigned to certain values in the tables indicate the absence or lack of statistically significant differences.

\section{Results and discussion}

The average values of the measured body weights of chickens from all the groups according to the fattening period are shown in Table 2.

Statistical analysis has shown that there was a statistically significant difference in the average body weights of chickens between the experimental groups and the control group on the $7^{\text {th }}, 14^{\text {th }}, 21^{\text {st }}$, $28^{\text {th }}, 35^{\text {th }}$ and $42^{\text {nd }}$ days of the fattening period.

The average values of the calculated weight gains of chickens from all the groups according to the fattening period are shown in Table 3.

Statistical analysis has shown that there was a statistically significant difference in the average weight gain of chickens between the experimental groups and the control group on the $1^{\text {st }}, 2^{\text {nd }}, 3^{\text {rd }}$, $4^{\text {th }}$ and $5^{\text {th }}$ weeks of the fattening period.

Considering the feed conversion ratio by groups of chickens and fattening periods the study revealed several differences. In the period from the $1^{\text {st }}$ to $3^{\text {rd }}$ weeks of fattening, the lowest feed conversion ratio (1.69) was recorded in the P4 group, and the highest (1.93) in the control group of chickens. In the period from $4^{\text {th }}$ to $6^{\text {th }}$ weeks of fattening, the lowest feed conversion ratio (2.38) was recorded in the $\mathrm{P} 1$ group, and the highest (2.52) in the P2 group of chickens. During the whole fattening period (from $1^{\text {st }}$ to $6^{\text {th }}$ weeks of fattening), the lowest feed conversion ratio (2.19) was recorded in the P1 and P4 groups, and the highest (2.31) in the P2 group of chickens.

The overall mortality rate was found to be $3.5 \%(7 / 200)$ during the study. The highest mortality rate of $10 \%(4 / 40)$ was recorded in the 
Table 2: Body weights of chickens according to the fattening period $(\mathrm{g})$

\begin{tabular}{|c|c|c|c|c|c|c|c|}
\hline \multirow{2}{*}{ Days } & \multirow{2}{*}{$\begin{array}{l}\text { Statistical } \\
\text { parameters }\end{array}$} & \multicolumn{5}{|c|}{ Group of chickens } & \multirow[b]{2}{*}{${ }^{*} P$ - value } \\
\hline & & $\mathrm{K}$ & $\mathrm{P} 1$ & $\mathrm{P} 2$ & P3 & P4 & \\
\hline \multirow{2}{*}{$1^{\text {st }}$} & $\bar{x}$ & 41.23 & 41.25 & 41.30 & 41.25 & 41.23 & \multirow{2}{*}{0.999} \\
\hline & $\mathrm{s}$ & 1.40 & 1.63 & 1.65 & 1.66 & 1,51 & \\
\hline \multirow{2}{*}{$7^{\text {th }}$} & $\bar{x}$ & $125.95^{\mathrm{a}}$ & $129.79^{\mathrm{ab}}$ & $131.95^{\mathrm{ab}}$ & $135.59^{\mathrm{b}}$ & $141.85^{c}$ & \multirow{2}{*}{0.001} \\
\hline & $\mathrm{s}$ & 18.39 & 17.05 & 14.61 & 15.17 & 17.43 & \\
\hline \multirow{2}{*}{$14^{\text {th }}$} & $\bar{x}$ & $303.89^{\mathrm{ac}}$ & $307.13^{\mathrm{a}}$ & $324.50^{\mathrm{cd}}$ & $341.23^{\mathrm{bd}}$ & $352.36^{b}$ & \multirow{2}{*}{$<0.001$} \\
\hline & $\mathrm{s}$ & 62.97 & 43.84 & 47.09 & 39.74 & 40.36 & \\
\hline \multirow{2}{*}{$21^{\text {st }}$} & $\bar{x}$ & $607.67^{a}$ & $655.51^{\mathrm{b}}$ & $670.33^{\mathrm{b}}$ & $719.90^{\circ}$ & $743.46^{c}$ & \multirow[b]{2}{*}{$<0.001$} \\
\hline & s & 112.42 & 93.47 & 95.86 & 84.90 & 82.16 & \\
\hline \multirow{2}{*}{$28^{\text {th }}$} & $\bar{x}$ & $1018.03^{a}$ & $1077.10^{\text {ad }}$ & $1106.30^{\mathrm{bd}}$ & $1140.51^{\mathrm{b}}$ & $1187.13^{c}$ & \multirow{2}{*}{$<0.001$} \\
\hline & s & 173.25 & 138.90 & 154.14 & 103.76 & 120.58 & \\
\hline \multirow{2}{*}{$35^{\text {th }}$} & $\bar{x}$ & $1526.03^{a}$ & $1581.15^{\mathrm{ab}}$ & $1599.95^{\mathrm{ab}}$ & $1665.33^{\mathrm{b}}$ & $1753.21^{\mathrm{c}}$ & \multirow{2}{*}{$<0.001$} \\
\hline & s & 250.78 & 191.95 & 251.52 & 152.78 & 192.93 & \\
\hline \multirow{2}{*}{$42^{\text {nd }}$} & $\bar{x}$ & $1961.67^{\mathrm{a}}$ & $1985.97^{a}$ & $1999.65^{\mathrm{ac}}$ & $2083.59^{\mathrm{bc}}$ & $2146.3^{b}$ & \multirow{2}{*}{0.002} \\
\hline & $\mathrm{s}$ & 289.95 & 214.49 & 291.48 & 185.28 & 229.17 & \\
\hline
\end{tabular}

*Kruskal-Wallis test

$\bar{x}=$ mean; $s=$ standard deviation; means within rows without common superscripts differ significantly ${ }^{a, b, c} P<0.05 ; K=$ control group; $P 1=$ feed mixture $+0.25 \mathrm{~g}$ of propolis $/ \mathrm{kg}$ of feed mixture $+20 \mathrm{~g}$ of bee pollen $/ \mathrm{kg}$ of feed mixture; $P 2=$ feed mixture $+0.5 \mathrm{~g}$ of propolis $/ \mathrm{kg}$ of feed mixture; $P 3=$ feed mixture $+1.0 \mathrm{~g}$ of propolis $/ \mathrm{kg}$ of feed mixture; $\mathrm{P} 4=$ feed mixture $+20 \mathrm{~g}$ of bee pollen $/ \mathrm{kg}$ of feed mixture.

$\mathrm{K}$ group. The $\mathrm{P} 1$, P3, and $\mathrm{P} 4$ groups had a $2.5 \%$ mortality rate, whereas in the P2 group no deaths of experimental animals were recorded. The study has shown that there was a statistically significant difference in mortality in the K group (10.0\%; 4/40) in comparison to all the other experimental groups (1.9\%; 3/160) (Fisher's exact test; $\mathrm{p}=0.031$ ). This result is consistent with the result of the study done by Khojasteh Shalmany and Shivazad (18), who found that the chickens fed with the addition of propolis to the amounts of 200 and $250 \mathrm{mg} /$ $\mathrm{kg}$ of feed mixture had much lower mortality rate than the $\mathrm{K}$ group of chickens. This study is also consistent with the results of the study by Omar et al. (19), who found that the chickens fed with the addition of propolis had better survival rate (95\%) than the K group of chickens (88.3\%). The positive effect of propolis/bee pollen in terms of mortality of chickens in this and similar studies can be explained by powerful antimicrobial (bactericidal, antiviral, antifungal and antiprotozoal) properties of bee products. Due to the mentioned antimicrobial properties, bee products are considered to prevent subclinical infections in chickens, while simultaneously acting as growth promoters (19). Apart from their antimicrobial properties, propolis / bee pollen have positive effects on the mortality of chickens as a result of their stimulation of the immune system by boosting the immune response of chickens and enhancing their resistance, thus directly reducing mortality in comparison to the $\mathrm{K}$ group chickens $(18,19)$. 
Table 3: Weekly weight gains of chickens (g)

\begin{tabular}{|c|c|c|c|c|c|c|c|}
\hline \multirow{2}{*}{ Weeks } & \multirow{2}{*}{$\begin{array}{l}\text { Statistical } \\
\text { parameters }\end{array}$} & \multicolumn{5}{|c|}{ Group of chickens } & \multirow{2}{*}{$\begin{array}{l}{ }^{*} P- \\
\text { value }\end{array}$} \\
\hline & & K & $\mathrm{P} 1$ & $\mathrm{P} 2$ & P3 & $\mathrm{P} 4$ & \\
\hline \multirow[b]{2}{*}{$1^{\text {st }}$} & $\bar{x}$ & $84.74^{\mathrm{a}}$ & $88.54^{\mathrm{ab}}$ & $90.65^{\mathrm{ab}}$ & $94.26^{\mathrm{b}}$ & $100.63^{c}$ & \multirow[b]{2}{*}{$<0.001$} \\
\hline & $\mathrm{s}$ & 17.20 & 16.01 & 13.26 & 13.66 & 17.55 & \\
\hline \multirow{2}{*}{$2^{\text {nd }}$} & $\bar{x}$ & $177.19^{\mathrm{a}}$ & $177.33^{\mathrm{a}}$ & $192.55^{\mathrm{ab}}$ & $205.64^{b}$ & $210.41^{b}$ & \multirow{2}{*}{0.002} \\
\hline & s & 55.68 & 45.83 & 50.26 & 40.55 & 38.77 & \\
\hline \multirow{2}{*}{$3^{\text {rd }}$} & $\bar{x}$ & $304.53^{a}$ & $348.38^{b}$ & $345.83^{b}$ & $378.67^{\mathrm{bc}}$ & $391.10^{c}$ & \multirow{2}{*}{$<0.001$} \\
\hline & $\mathrm{s}$ & 106.41 & 97.72 & 93.27 & 88.04 & 82.74 & \\
\hline \multirow{2}{*}{$4^{\text {th }}$} & $\bar{x}$ & $410.36^{a}$ & $421.59^{\mathrm{ab}}$ & $435.98^{b}$ & $420.62^{\mathrm{a}}$ & $443.67^{b}$ & \multirow{2}{*}{0.029} \\
\hline & $\mathrm{s}$ & 66.18 & 57.09 & 75.02 & 36.25 & 52.10 & \\
\hline \multirow{2}{*}{$5^{\text {th }}$} & $\bar{x}$ & $508.00^{\mathrm{a}}$ & $504.05^{\mathrm{a}}$ & $493.65^{a}$ & $524.82^{\mathrm{a}}$ & $566.08^{\mathrm{b}}$ & \multirow{2}{*}{0.009} \\
\hline & $\mathrm{s}$ & 87.17 & 83.40 & 117.53 & 68.36 & 94.89 & \\
\hline \multirow{2}{*}{$6^{\text {th }}$} & $\bar{x}$ & 435.64 & 404.82 & 399.70 & 418.26 & 393.10 & \multirow{2}{*}{0.123} \\
\hline & $\mathrm{s}$ & 64.88 & 75.78 & 74.85 & 68.27 & 84.59 & \\
\hline
\end{tabular}

*Kruskal-Wallis test

$\bar{x}=$ mean; $s=$ standard deviation; means within rows without common superscripts differ significantly ${ }^{a, b, c} P<0.05 ; K=$ control group; $P 1=$ feed mixture $+0.25 \mathrm{~g}$ of propolis $/ \mathrm{kg}$ of feed mixture $+20 \mathrm{~g}$ of bee pollen $/ \mathrm{kg}$ of feed mixture; $P 2=$ feed mixture $+0.5 \mathrm{~g}$ of propolis $/ \mathrm{kg}$ of feed mixture; $P 3=$ feed mixture $+1.0 \mathrm{~g}$ of propolis $/ \mathrm{kg}$ of feed mixture; $\mathrm{P4}=$ feed mixture $+20 \mathrm{~g}$ of bee pollen $/ \mathrm{kg}$ of feed mixture.

The values of the investigated haematological parameters in chickens' blood on the $21^{\text {st }}$ day of the fattening period according to the specific group of chickens are shown in Table 4. Statistical analysis has shown that there was a statistically significant difference in the values of $\mathrm{MCV}, \mathrm{MCHC}$ and haematocrit, leukocyte count and relative Mo ratio, while there was no statistically significant difference in the erythrocyte count, values of haemoglobin and $\mathrm{MCH}$ and the relative ratio of $\mathrm{He}$, Ly, Eo and $\mathrm{Ba}$ between the analysed groups of chickens on the $21^{\text {st }}$ day of the fattening period. The results of this study are in contrast to those of the study by Eyng et al. (20) who found no statistically significant differences in the relative ratios of heterophils, lymphocytes, monocytes and basophils between the control and experimental groups. However, they did find statistically significant differences in the relative ratio of eosinophils between the groups. Furthermore, taking into consideration the values of the monocytes determined in our study, it is clear that they are opposite to those of the study by Eyng et al. (20). Specifically, the highest relative ratio of monocytes in our study was recorded in the $\mathrm{K}$ group of chickens and the lowest in the P4 and P3 groups of chickens (the highest amount of bee pollen in P4 and the highest amount of propolis in P3), in contrast to Eyng et al. (20) who found that the highest relative ratio of monocytes was determined in the blood of chickens that were fed with the addition of 200 ppm of propolis (mean amount of propolis), and the lowest relative ratio of monocytes was found in the blood of the $\mathrm{K}$ group of chickens.

The values of the investigated haematological parameters in chickens' blood on the $42^{\text {nd }}$ day of the fattening period according to the specific group of chickens are shown in Table 5. Statistical analysis has shown that there was a statistically significant difference in the relative ratio of $\mathrm{He}$, Ly and Mo, while there was no statistically significant 
Table 4: Haematological parameters in chickens' blood on the 21 st day of the fattening period

\begin{tabular}{|c|c|c|c|c|c|c|}
\hline \multirow{2}{*}{ Parameters } & \multicolumn{5}{|c|}{$\begin{array}{c}\text { Group of chickens } \\
\bar{x} \pm \mathrm{s}\end{array}$} & \multirow{2}{*}{$\begin{array}{c}P- \\
\text { value }\end{array}$} \\
\hline & $\mathrm{K}$ & $\mathrm{P} 1$ & $\mathrm{P} 2$ & P3 & P4 & \\
\hline $\begin{array}{c}\mathrm{E} \\
\left(10^{12} / \mathrm{L}\right)\end{array}$ & $2.29 \pm 0.13$ & $2.21 \pm 0.14$ & $2.32 \pm 0.19$ & $2.29 \pm 0.13$ & $2.38 \pm 0.15$ & $0.186^{*}$ \\
\hline $\begin{array}{l}\mathrm{Hb} \\
(\mathrm{g} / \mathrm{L})\end{array}$ & $107.70 \pm 6.31$ & $105.10 \pm 5.47$ & $110.90 \pm 8.36$ & $107.90 \pm 5.36$ & $111.40 \pm 7.62$ & $0.122^{\dagger}$ \\
\hline $\begin{array}{l}\text { Htc } \\
(\mathrm{L} / \mathrm{L})\end{array}$ & $0.274^{\mathrm{ac}} \pm 0.017$ & $0.265^{a} \pm 0.015$ & $0.281^{\mathrm{abc}} \pm 0.022$ & $0.285^{b c} \pm 0.014$ & $0.292^{\mathrm{b}} \pm 0.020$ & $0.015^{\dagger}$ \\
\hline $\begin{array}{l}\mathrm{MCV} \\
\text { (fL) }\end{array}$ & $119.46^{\mathrm{ab}} \pm 4.08$ & $119.92^{\mathrm{a}} \pm 1.17$ & $121.23^{\mathrm{ab}} \pm 2.26$ & $124.38^{\mathrm{b}} \pm 2.93$ & $122.86^{\mathrm{ab}} \pm 4.76$ & $0.009^{*}$ \\
\hline $\begin{array}{c}\mathrm{MCH} \\
(\mathrm{pg})\end{array}$ & $47.01 \pm 1.67$ & $47.56 \pm 1.14$ & $47.77 \pm 1.02$ & $47.15 \pm 1.27$ & $46.87 \pm 1.40$ & $0.515^{*}$ \\
\hline $\begin{array}{l}\mathrm{MCHC} \\
(\mathrm{g} / \mathrm{L})\end{array}$ & $393.70^{\mathrm{a}} \pm 9.17$ & $396.40^{\mathrm{a}} \pm 8.24$ & $394.20^{\mathrm{a}} \pm 6.51$ & $379.10^{\mathrm{b}} \pm 5.17$ & $381.10^{\mathrm{b}} \pm 8.71$ & $<0.001^{*}$ \\
\hline $\begin{array}{c}\mathrm{L} \\
\left(10^{9} / \mathrm{L}\right)\end{array}$ & $13.80^{\mathrm{ab}} \pm 6.36$ & $12.80^{\mathrm{ab}} \pm 5.51$ & $12.40^{\mathrm{a}} \pm 2.95$ & $19.20^{\mathrm{b}} \pm 5.35$ & $13.40^{\mathrm{ab} \pm 4.62}$ & $0.029^{*}$ \\
\hline $\begin{array}{l}\mathrm{He} \\
(\%)\end{array}$ & $42.50 \pm 6.10$ & $48.30 \pm 5.33$ & $47.90 \pm 7.34$ & $48.90 \pm 6.08$ & $47.20 \pm 7.74$ & $0.211^{*}$ \\
\hline $\begin{array}{l}\text { Ly } \\
(\%)\end{array}$ & $50.40 \pm 5.50$ & $48.70 \pm 4.79$ & $48.80 \pm 8.39$ & $48.80 \pm 6.07$ & $50.60 \pm 7.81$ & $0.934^{*}$ \\
\hline $\begin{array}{l}\text { Eo } \\
(\%)\end{array}$ & $2.70 \pm 2.06$ & $1.60 \pm 1.51$ & $1.70 \pm 1.25$ & $1.40 \pm 1.51$ & $2.20 \pm 0.92$ & $0.308^{*}$ \\
\hline $\begin{array}{l}\text { Mo } \\
(\%)\end{array}$ & $3.70^{\mathrm{a}} \pm 3.06$ & $1.10^{\mathrm{b}} \pm 1.85$ & $1.50^{\mathrm{abc}} \pm 1.27$ & $0.70^{b} \pm 0.95$ & $0.10^{c} \pm 0.32$ & $<0.001^{\dagger}$ \\
\hline $\begin{array}{l}\mathrm{Ba} \\
(\%)\end{array}$ & $0.70 \pm 0.82$ & $0.30 \pm 0.68$ & $0.10 \pm 0.32$ & $0.20 \pm 0.42$ & $0.00 \pm 0.00$ & $0.063^{\dagger}$ \\
\hline
\end{tabular}

${ }^{*}$ ANOVA; ${ }^{\dagger}$ Kruskal-Wallis test

$\bar{x}=$ mean; $s=$ standard deviation; means within rows without common superscripts differ significantly ${ }^{a, b, c} P<0.05 ; K=$ control group; $P 1=$ feed mixture $+0.25 \mathrm{~g}$ of propolis $/ \mathrm{kg}$ of feed mixture $+20 \mathrm{~g}$ of bee pollen $/ \mathrm{kg}$ of feed mixture; $P 2=$ feed mixture $+0.5 \mathrm{~g}$ of propolis $/ \mathrm{kg}$ of feed mixture; $P 3=$ feed mixture $+1.0 \mathrm{~g}$ of propolis $/ \mathrm{kg}$ of feed mixture; $\mathrm{P} 4=$ feed mixture $+20 \mathrm{~g}$ of bee pollen $/ \mathrm{kg}$ of feed mixture. 
Table 5: Haematological parameters in chickens' blood on the $42^{\text {nd }}$ day of the fattening period

\begin{tabular}{|c|c|c|c|c|c|c|}
\hline \multirow{2}{*}{ Parameters } & \multicolumn{5}{|c|}{$\begin{array}{c}\text { Group of chickens } \\
\bar{x} \pm \mathrm{s}\end{array}$} & \multirow{2}{*}{$\begin{array}{c}P- \\
\text { value }\end{array}$} \\
\hline & $\mathrm{K}$ & $\mathrm{P} 1$ & $\mathrm{P} 2$ & P3 & P4 & \\
\hline $\begin{array}{c}\mathrm{E} \\
\left(10^{12} / \mathrm{L}\right)\end{array}$ & $2.23 \pm 0.10$ & $2.26 \pm 0.15$ & $2.45 \pm 0.31$ & $2.36 \pm 0.31$ & $2.46 \pm 0.14$ & $0.083^{*}$ \\
\hline $\begin{array}{l}\mathrm{Hb} \\
(\mathrm{g} / \mathrm{L})\end{array}$ & $100.40 \pm 3.78$ & $101.00 \pm 6.57$ & $109.30 \pm 13.43$ & $104.90 \pm 12.79$ & $109.30 \pm 7.80$ & $0.110^{*}$ \\
\hline $\begin{array}{l}\mathrm{Htc} \\
(\mathrm{L} / \mathrm{L})\end{array}$ & $0.268 \pm 0.164$ & $0.274 \pm 0.023$ & $0.289 \pm 0.036$ & $0.281 \pm 0.037$ & $0.289 \pm 0.022$ & $0.376^{*}$ \\
\hline $\begin{array}{l}\mathrm{MCV} \\
\text { (fL) }\end{array}$ & $120.18 \pm 3.94$ & $121.19 \pm 4.95$ & $118.04 \pm 4.66$ & $119.44 \pm 4.56$ & $117.72 \pm 4.18$ & $0.390^{*}$ \\
\hline $\begin{array}{c}\mathrm{MCH} \\
(\mathrm{pg})\end{array}$ & $44.99 \pm 1.26$ & $44.64 \pm 0.92$ & $44.63 \pm 0.89$ & $44.52 \pm 1.12$ & $44.44 \pm 1.53$ & $0.861^{*}$ \\
\hline $\begin{array}{c}\mathrm{MCHC} \\
(\mathrm{g} / \mathrm{L})\end{array}$ & $375.90 \pm 13.75$ & $368.90 \pm 10.37$ & $378.50 \pm 10.86$ & $373.30 \pm 7.90$ & $377.80 \pm 10.04$ & $0.278^{*}$ \\
\hline $\begin{array}{c}\mathrm{L} \\
\left(10^{9} / \mathrm{L}\right)\end{array}$ & $30.80 \pm 15.32$ & $28.40 \pm 17.04$ & $32.80 \pm 17.05$ & $44.00 \pm 12.75$ & $36.60 \pm 13.30$ & $0.189^{*}$ \\
\hline $\begin{array}{l}\mathrm{He} \\
(\%)\end{array}$ & $37.50^{\mathrm{a}} \pm 8.48$ & $50.30^{\mathrm{bd}} \pm 5.54$ & $45.40^{\mathrm{be}} \pm 7.52$ & $42.80^{\mathrm{ae}} \pm 7.12$ & $53.70^{\mathrm{cd}} \pm 7.23$ & $<0.001^{*}$ \\
\hline $\begin{array}{l}\text { Ly } \\
(\%)\end{array}$ & $58.70^{\mathrm{a}} \pm 7.88$ & $47.00^{\mathrm{bc}} \pm 4.90$ & $52.50^{\mathrm{ac}} \pm 7.98$ & $55.30^{\mathrm{a}} \pm 7.39$ & $43.80^{\mathrm{b}} \pm 6.68$ & $<0.001^{*}$ \\
\hline $\begin{array}{l}\text { Eo } \\
(\%)\end{array}$ & $2.50 \pm 1.51$ & $1.20 \pm 1.23$ & $1.60 \pm 0.84$ & $1.50 \pm 0.85$ & $2.00 \pm 1.70$ & $0.350^{\dagger}$ \\
\hline $\begin{array}{l}\text { Mo } \\
(\%)\end{array}$ & $0.60^{\mathrm{ab}} \pm 0.70$ & $0.90^{\mathrm{a}} \pm 0.74$ & $0.10^{\mathrm{b}} \pm 0.32$ & $0.30^{\mathrm{ab}} \pm 0.48$ & $0.20^{\mathrm{b}} \pm 0.42$ & $0.027^{\dagger}$ \\
\hline $\begin{array}{l}\mathrm{Ba} \\
(\%)\end{array}$ & $0.70 \pm 0.95$ & $0.60 \pm 0.70$ & $0.40 \pm 0.70$ & $0.10 \pm 0.32$ & $0.30 \pm 0.48$ & $0.280^{\dagger}$ \\
\hline
\end{tabular}

*ANOVA; ${ }^{\dagger}$ Kruskal-Wallis test

$\bar{x}=$ mean; $s=$ standard deviation; means within rows without common superscripts differ significantly $\quad$ a,b,c $P<0.05 ; K=$ control group; $P 1=$ feed mixture $+0.25 \mathrm{~g}$ of propolis $/ \mathrm{kg}$ of feed mixture $+20 \mathrm{~g}$ of bee pollen $/ \mathrm{kg}$ of feed mixture; $P 2=$ feed mixture $+0.5 \mathrm{~g}$ of propolis $/ \mathrm{kg}$ of feed mixture; $P 3=$ feed mixture

$+1.0 \mathrm{~g}$ of propolis $/ \mathrm{kg}$ of feed mixture; $\mathrm{P} 4=$ feed mixture $+20 \mathrm{~g}$ of bee pollen $/ \mathrm{kg}$ of feed mixture. 
difference in the erythrocyte and leukocyte count, values of haemoglobin, haematocrit, $\mathrm{MCV}, \mathrm{MCH}$ and $\mathrm{MCHC}$ and the relative ratio of Eo and $\mathrm{Ba}$ between the analysed groups of chickens on the $42^{\text {nd }}$ day of the fattening period. This study, similar to one done by Omar et al. (19), has shown that all the experimental groups of chickens (P1-P4) had more erythrocytes and higher values of haemoglobin in relation to the $\mathrm{K}$ group of chickens; however, the aforementioned differences had no statistical significance. Furthermore, this study has shown that P2, P3 and P4 groups of chickens had more leukocytes in relation to the $\mathrm{K}$ group but having no statistically significant difference. In terms of the relative ratios of the individual leukocyte types, this study has shown that all the experimental groups of chickens (P1-P4) had higher values of heterophils and lower values of lymphocytes, eosinophils and basophils in comparison to the $\mathrm{K}$ group of chickens. With respect to monocytes, the study has shown that the P2, P3 and P4 groups of chickens had lower relative ratios of this type of leukocytes in comparison to the K group, whereas the $\mathrm{P} 1$ group of chickens had higher relative ratio of monocytes in comparison to the $\mathrm{K}$ group. In their research, Ziaran et al. (21) found that the chickens fed with the addition of propolis had a significantly lower relative ratio of heterophils and a significantly higher relative ratio of lymphocytes on the $47^{\text {th }}$ day of fattening in comparison to the chickens of the control group, while there was no statistically significant difference in the relative ratios of eosinophils and monocytes between the chickens of the control and experimental groups. These results are in contrast to the results of the previously mentioned research by Ziaran et al. (21).

The results of this study are also contrary to the results of the study by Shahryar et al. (5), who found that on the $42^{\text {nd }}$ day of fattening there were no statistically significant differences in the erythrocyte and leukocyte count and the relative ratios of heterophils, lymphocytes, eosinophils, monocytes, and basophils between the experimental groups of chickens fed with the addition of various amounts of propolis and the chickens in the control group.

In their study, Attia et al. (1) found that the chickens in the experimental groups fed with the addition of propolis and/or bee pollen had on the $35^{\text {th }}$ day of fattening significantly more erythrocytes, higher values of haemoglobin, lower values of $\mathrm{MCV}$, roughly the same values of $\mathrm{MCH}$, and higher values of $\mathrm{MCHC}$ compared to the control group of chickens. These results are opposite to the results of our study, in which no statistically significant differences either in the erythrocyte count or values of haemoglobin $\mathrm{MCV}, \mathrm{MCH}$, and $\mathrm{MCHC}$ have been found. When analysing $\mathrm{RBC}$ parameters in chickens' blood in relation to the reference values of those parameters according to Wakenell (17), it can be said that the values of haemoglobin, haematocrit $\mathrm{MCV}, \mathrm{MCH}$, and $\mathrm{MCHC}$ and the erythrocyte count observed in our study are generally consistent with the previously mentioned reference values.

When analysing the effect of propolis and bee pollen on the values of RBC parameters in the blood of chickens on the $21^{\text {st }}$ and $42^{\text {nd }}$ days of fattening, this study has indicated that propolis and/or bee pollen positively affected the red blood cell count of broiler chickens. Accordingly, on the $21^{\text {st }}$ day of fattening, higher values of haemoglobin, haematocrit $\mathrm{MCV}, \mathrm{MCH}$, and $\mathrm{MCHC}$ and more erythrocytes were determined in the experimental groups of chickens when compared to the K group of chickens. On the last day of fattening $\left(42^{\text {nd }}\right.$ day), higher values of haemoglobin, haematocrit and more erythrocytes were again found in the experimental groups of chickens when compared to the $\mathrm{K}$ group. The aforementioned increase in $\mathrm{RBC}$ parameters determined in this study can be explained by better nutrient utilization in chickens fed with a feed mixture containing propolis or bee pollen, thus resulting in the better health condition of the chickens in general (1). Furthermore, studies by other authors have demonstrated that propolis significantly improves the digestive utilization of iron and haemoglobin regeneration efficiency $(22,23)$. As regard to the effect of bee pollen, studies have shown that adding it to feed increases haemoglobin levels in animals' blood, as well as serum iron levels, resulting in better red blood cell counts (24). Furthermore, Omar et al. (19) have established that higher values of haemoglobin, erythrocyte count, total proteins and individual protein fractions in the blood of the chickens fed with the addition of propolis may be the result of a direct effect of propolis on the anabolic processes in the context of protein synthesis in the hematopoietic tissue of chickens, thus protecting body proteins against degradation. Bearing in mind that flavonoids are the main bioactive components 
of propolis and bee pollen, which, among other effects, have strong antioxidant properties, it is most likely that these antioxidant properties prevent lipid oxidation in muscle cells, as well as in erythrocytes. Consequently, a decrease in lipid oxidation contributes to the better stability of red blood cell membranes and lower susceptibility of erythrocytes to haemolysis, thus having a positive effect on the erythrocyte count in the blood of the chickens fed with the mentioned additives $(25,26)$.

When comparing WBC count parameters with the reference values according to Wakenell (17), it can be said that the values of the leukocyte count and the relative ratios of heterophils, lymphocytes, eosinophils, monocytes and basophils observed in our study are generally consistent with the previously mentioned reference values.

When analysing the effect of propolis and bee pollen on the values of WBC parameters in the blood of chickens on the $21^{\text {st }}$ and $42^{\text {nd }}$ day of fattening, this study has shown that the mentioned additives affect white blood cell count of broiler chickens. Accordingly, on the $21^{\text {st }}$ day of fattening, the P3 group had higher and P1, P2, and $\mathrm{P} 4$ groups lower values of leukocytes when compared to the K group of chickens. During that period, a higher relative ratio of heterophils and lower relative ratios of lymphocytes, eosinophils, monocytes, and basophils were found in all the experimental groups of chickens. On the last day of fattening ( $42^{\text {nd }}$ day), the P2, P3, and P4 groups had higher values and the P1 group lower values of leukocytes in comparison to the $\mathrm{K}$ group of chickens. Furthermore, during that period higher relative ratio of heterophils and lower relative ratios of lymphocytes, eosinophils, monocytes, and basophils were found in all the experimental groups of chickens. In birds, heterophils are phagocytic cells, and their primary role is to protect animals from the attacks of different microorganisms, whereas the primary role of lymphocytes implies cell-mediated and humoral immune response (27).

Taking into consideration the results of this study in terms of white blood cells, it can be concluded that the addition of propolis and bee pollen increases the relative ratio of heterophils and decreases the relative ratio of lymphocytes in the blood. The explanation may lie in the fact that synergism of different flavonoids that bee products contain has an immunosuppressive effect on the lymphoproliferative response in chickens due to nitric oxide production from macrophages which are responsible for the inhibition of DNA synthesis in different cells (21), and various studies have shown that bioactive components of propolis and bee pollen stimulate macrophage activation (28). Finally, it can be concluded that propolis and bee pollen have strong immunomodulatory effects through macrophage activation but no effect on the lymphocyte proliferation, as evident in this study from the differential blood count of chickens with higher relative ratios of heterophils and lower relative ratios of lymphocytes. Additional explanation of the results of this study as regards to the relative ratios of heterophils and lymphocytes lies in the fact that the chickens fed with the addition of propolis and bee pollen were thus exposed to antioxidant properties of flavonoids, as the most important bioactive components of these additives, and studies have shown that antioxidants intensify the phagocytic activity of heterophils (29).

\section{Conclusions}

The present study has undoubtedly determined that the addition of propolis and/or bee pollen to feed mixtures has significant positive effects on the performance parameters of broilers. Given the fact that lower mortality was recorded in all the experimental groups when compared to the control group of chickens, it can be concluded that the general health condition of chickens is improved by adding propolis and/or bee pollen into their feed mixture. Propolis and bee pollen also positively affect the values of the red blood cell count, since significantly higher values of $\mathrm{MCV}$ and haematocrit were recorded in the experimental groups of chickens in comparison to the control group on the $21^{\text {st }}$ day of fattening. The investigated additives also have a significant positive effect on the values of white blood cells. Specifically, experimental groups of chickens had, in relation to the control group, significantly lower values of the leukocyte count and of the relative ratio of monocytes on the $21^{\text {st }}$ day of fattening. On the $42^{\text {nd }}$ day of fattening, the experimental groups of chickens had, in relation to the control group, significantly higher values of the relative ratio of heterophils and significantly lower values of the relative ratios of lymphocytes and monocytes.

Finally, this study has shown that propolis and 
bee pollen (either separately or in combination) have a significant positive impact on the performance, the mortality and the values of the selected haematological blood parameters in chickens. To maximize the efficacy of the investigated natural feeding additives in commercial chicken production, it is necessary to further evaluate the administration level of these substances in chicken feed.

\section{References}

1. Attia YA, Abd Al-Hamid AE, Ibrahim MS, Al-Harthi MA, Bovera F, Elnaggar A Sh. Productive performance, biochemical and hematological traits of broiler chickens supplemented with propolis, bee pollen, and mannan oligosaccharides continuously or intermittently. Livest Sci 2014; 164: 87-95.

2. Abou-Zeid AE, El-Damarawy SZ, Mariey YA, El-Kasass SM. Effect of dietary propolis supplementation on performance and activity of antioxidant enzymes in broiler chickens. Egypt J Nutr Feeds 2015; 18: 391-400.

3. Kahraman T, Issa G, Altunatmaz SS, et al. Effects of oregano essential oil, grapefruit seed extract and their combination on the growth and survival of Salmonella typhimurium and Listeria monocytogenes in poultry fillets under modified atmosphere packaging. Slov Vet Res 2016; 53: 5-12.

4. Kleczek K, Majewska K, Makowski W, Michalik D. The effect of diet supplementation with propolis and bee pollen on the physicochemical properties and strength of tibial bones in broiler chickens. Arch Tierzucht 2012; 55: 97-103.

5. Shahryar HA, Namvari M, Nourollahi H, Tili AS. Effect of alcoholic extract propolis on immune system in broiler chickens. J Basic Appl Sci Res 2011; 1: 2094-7.

6. Sforcin JM. Propolis and the immune system: a review. J Ethnopharmacol 2007; 113: 1-14.

7. Lotfy M. Biological activity of bee propolis in health and disease. Asian Pac J Cancer Prev 2006; 7: 22-31.

8. Tatli Seven P, Yilmaz S, Seven I, Cerci IH, Azman MA, Yilmaz M. Effects of propolis on selected blood indicators and antioxidant enzyme activities in broilers under heat stress. Acta Vet Brno 2009; 78: 75-83.

9. Talas ZS, Gulhan MF. Effects of various propolis concentrations on biochemical and hematological parameters of rainbow trout (Oncorhynchus mykiss). Ecotoxicol Environ Saf 2009; 72: 1994-8.

10. Eyng C, Murakami AE, Pedroso RB, Silveira TGV, Lourenço DAL, Garcia AFQM. Crude propolis as an immunostimulating agent in broiler feed during the starter phase. Semin Ciênc Agrár 2013; 34: 2511-22.

11. Babinska I, Kleczek K, Szarek J, Makowski W. Modulating effect of propolis and bee pollen on chicken breeding parameters and pathomorphology of liver and kidneys in the course of natural infection with Salmonella enteritidis. Bull Vet Inst Pulawy 2012; 56: 3-8.

12. Pascoal A, Rodrigues S, Teixeira A, Feas X, Estevinho LM. Biological activities of commercial bee pollens: antimicrobial, antimutagenic, antioxidant and anti-inflammatory. Food Chem Toxicol 2014; 63: 233-9.

13. Hascík P, Elimam IOE, Garlík J, Bobko M, Krocko M. Sensory evaluation of broiler meat after addition Slovak bee pollen in their feed mixture. Potravinarstvo 2013; 7: 107-10.

14. Capcarova M, Kolesarova A, Kalafova A, et al. The role of dietary bee pollen in antioxidant potential in rats. Eurasian J Vet Sci 2013; 29: $133-7$.

15. Kacániová M, Hascík P, Arpásová H, et al. Enterococcus genus identification isolated from gastrointestinal tract of chickens after bees' products application using MALDI TOF MS biotyper. SPASB 2013; 46: 114-8.

16. Aviagen. Ross 308 Broiler: performance objectives. Huntsville: Aviagen Group, 2012.

17. Wakenell PS. Hematology of chickens and turkeys. In: Weiss DJ, Wardrop KJ, eds. Schalm's veterinary hematology. 6th ed. Ames: Blackwell Publishing, 2010: 958-67.

18. Khojasteh Shalmany S, Shivazad M. The effect of diet propolis supplementation on Ross broiler chicks' performance. Int J Poult Sci 2006; 5: 84-8.

19. Omar REM, Mahmoud EA, Karousa MM, Randa SA. Effects of additives propolis and Nigella sativa seed oil on some behavioural patterns, performance products and blood parameters in Sasso chickens. Egypt Poult Sci 2002; 21: 140-51.

20. Eyng C, Murakami AE, Duarte CRA, Santos TC. Effect of dietary supplementation with an ethanolic extract of propolis on broiler intestinal morphology and digestive enzyme activity. J Anim 
Physiol Anim Nutr 2014; 98: 393-401.

21. Ziaran HR, Rahmani HR, Pourezza J. Effect of dietary oil extract of propolis on immune response and broiler performance. Pak J Biol Sci 2005; 8: 1485-90.

22. Bratter C, Tregel M, Liebenthal C, Volk H. Prophylactic effectiveness of propolis for immunostimulation a clinical pilot study. Forsch Komplementarmed Klass Naturheilkd 1999; 6: 256-60.

23. Haro A, Lopez-Aliaga F, Lisbona M, Barrionuevo MJ, Alferez M, Campos MS. Beneficial effect of pollen and propolis on the metabolism of iron, calcium, phosphorous, and magnesium in rats with nutritional ferropenic anemia. J Agric Food Chem 2000; 48: 5715-22.

24. Gene B. Bee pollen, propolis \& royal jelly: smart supplementation. Knoxville: Huntington College of Health Sciences, 2005.

25. Romani A, Coinu R, Carta S, et al. Evaluation of antioxidant effect of different extracts of Myrtus communis L. Free Radic Res 2004; 38: 97-103.
26. Mahmoodi Bardzardi M, Ghazanfari S, Salehi A, Sharifi SD. Growth performance, carcass characteristics, antibody titer and blood parameters in broiler chickens fed dietary myrtle (Myrtus communis) essential oil as an alternative to antibiotic growth promoter. Poultry Sci J 2014; 2: 36-48.

27. Galal A, Abd El-Motaal AM, Ahmed AMH, Zaki TG. Productive performance and immune response of laying hens as affected by dietary propolis supplementation. Int J Poult Sci 2008; 7: 272-8.

28. Dimov V, Ivanovska N, Manolova N, Bankova V, Nikolov N, Popov S. Immunomodulatory action of propolis. Influence on anti-infectious protection and macrophage function. Apidologie 1991; 22: 155-62.

29. Klaric I. Production and health effects of propolis and bee pollen as food additives in broilers feeding. Osijek: Josip Juraj Strossmayer University of Osijek, Faculty of Agriculture, 2014. (PhD dissertation in Croatian)

\title{
VPLIV CVETNEGA PRAHU IN PROPOLISA NA RAST, SMRTNOST IN NEKATERE HEMATOLOŠKE KAZALNIKE PRI PIŠČANCIH BROJLERJIH
}

\author{
I. Klarić, M. Domaćinović, V. Šerić, I. Miškulin, M. Pavić, K. Paradinović
}

Povzetek: Namen raziskave je bil ugotoviti, kako cvetni prah ali propolis posamezno ali v kombinaciji vplivata na prirast, smrtnost in nekatere hematološke kazalnike pri piščancih brojlerjih. V raziskavo je bilo vključenih 200 piščancev brojlerjev pasme ross308. Piščanciso bili razdeljeninaključnov pet poskusnih skupin, vkaterih sta bila enakomerno zastopana oba spola. Kontrolna skupina piščancev je ves čas raziskave prejemala navadno hrano za brojlerje, medtem ko so 4 poskusne skupine prejemale hrano $z$ dodatkom cvetnega prahu in sicer skupina 1 (P1) 0,25 g propolisa in $20 \mathrm{~g}$ cvetnega prahu/kg hrane, skupina 2 (P2) 0,5 g propolisa/kg hrane, skupina 3(P3) $1 \mathrm{~g}$ propolisa/kg hrane in skupina 4(P4)20 g cvetnega prahu/kg hrane. Telesna teža piščancev je bila statistično značilno višja 1. ( $p<0,001), 2$. ( $p<0,001)$ in 5 . ( $p<0,01)$ teden raziskave v vseh poskusnih skupinah v primerjavi s kontrolno skupino. Podobno je bil tudi povprečen dnevni prirast pri piščancih iz poskusnih skupin statistično značilno višji 1. ( $p<$ $0,001), 2$. $(p<0,01), 3$. $(p<0,001), 4$. $(p<0,05)$ in 5 . $(p<0,01)$ teden raziskave. Tudi smrtnost je bila statistično značilno nižja v vseh poskusnih skupinah v primerjavi s kontrolno skupino $(p<0,05)$. Piščanci iz poskusnih skupin so imeli21. dan poskusa v povprečju višje vrednosti MCV $(p<0,01)$ in hematokrita $(p<0,05)$ ter nižje povprečno število levkocitov $(p<0,05)$ in relativno razmerje $M O(p<$ $0,001)$. Na 42. dan poskusa smo ugotovili višje vrednosti razmerja med heterofilci $(p<0,001)$ ter nižje relativne vrednosti limfocitov $(p<0,001)$ in monocitov $(p<0,05)$ pri piščancih iz poskusnih skupin v primerjavis piščanci izkontrolne skupine. Rezultati raziskave kažejo, da dodajanje propolisa ali cvetnega prahu izboljša splošno zdravstveno stanje piščancev brojlerjev ter posledično izboljša njihov prirast ter zviša telesno maso, zato bi se ju lahko uporabljalo kot dodatka k hrani za piščance brojlerje.

Ključne besede: piščanci; prirast; zdravstveno stanje; propolis; cvetni prah 